\title{
Sacralizing the City: The Begums of Bhopal and their Mosques
}

\author{
Jyoti Pandey Sharma
}

\begin{abstract}
Princely building ventures in post 1857 colonial India included, among others, construction of religious buildings, even as their patrons enthusiastically pursued the colonial modernist agenda. This paper examines the architectural patronage of the Bhopal Begums, the women rulers of Bhopal State, who raised three grand mosques in their capital, Bhopal, in the $19^{\text {th }}$ and early $20^{\text {th }}$ century. As Bhopal marched on the road to progress under the Begums' patronage, the mosques heralded the presence of Islam in the city in the post uprising scenario where both Muslims and mosques were subjected to retribution for fomenting the 1857 insurrection. Bhopal's mosques were not only sacred sites for the devout but also impacted the public realm of the city. Their construction drew significantly on the Mughal architectural archetype, thus affording the Begums an opportunity to assert themselves, via their mosques, as legitimate inheritors of the Mughal legacy, including taking charge of the latter's legacy of stewardship of Islam. Today, the Bhopal mosques constitute an integral part of the city's built heritage corpus. It is worth underscoring that they are not only important symbols of the Muslim faith but also markers of their patrons' endeavour to position themselves at the forefront in the complex political and cultural scenario of post uprising colonial India.
\end{abstract}

Keywords Bhopal Begums; Modernity; Mosques; Mughal legacy; Uprising

\section{INTRODUCTION}

The architecture of British ruled Indian Subcontinent has been a popular subject of scholarship from the colonial perspective with the architectural patronage of princely India also receiving due academic attention ${ }^{1}$. The latter has tended to be centered largely on personal princely building enterprise, notably palaces and retreats, and on commissioning of public works in keeping with the colonial state's post-uprising modernization agenda. Patronage of religious architecture by princely India is an area of study that has not received the attention it deserves. Indeed, the body of work focussing on non-religious architecture almost seems to convey that, in British $R a j$ (rule), building for God did not find favour with Indian rulers, irrespective of their religious affiliations.

1 For a discussion on the architecture of Indian Princes in colonial India, the following are recommended: G.H.R. Tillotson (1989) The Tradition of Indian Architecture: Continuity, Controversy and Change since 1850. Delhi: Oxford University Press and A. Volwahsen (2004) Splendours of Imperial India-British Architecture in the 18th and 19th Centuries. London: Prestel-Verlag.

Creative Space Vol. 1, No. 2 January 2014 pp. $145-165$

ChITKARA 司 UNIVERSITY

(C) 2014 by Chitkara University. All Rights

Reserved. 

of mosques by Muslim rulers in post-uprising British Raj in a climate of indigenous zeal for improvements in conformity with the norms of metropolitan modernity ${ }^{2}$. It examines the architectural patronage of the women rulers of Bhopal state, the Bhopal Begums (imperial women), who raised grand mosques in their capital, Bhopal, in the $19^{\text {th }}$ and early $20^{\text {th }}$ century, even as they steadfastly subscribed to model princely conduct laid down by the colonial regime. While several mosques were built in the city, this paper examines three Begumi (belonging to / patronized by imperial women) mosques, the Jami Masjid, Moti Masjid and Taj-ul Masjid, all built over a time span of about forty years. The mosques were not only sacred sites for the devout but also significantly impacted the public realm of the city. That the Bhopal mosques have received scant academic attention is borne by the fact that the many scholarly works devoted to the study of mosques of the Indian Subcontinent fail to mention them ${ }^{3}$.

\section{THE CONTEXT}

Post-uprising British India comprised an assortment of over 500 princely states that had been granted autonomy in lieu of loyalty. The colonial state relied on Indian princes for ushering change to realize its vision of a progressive India (Metcalf, 1989). Model princely conduct, as outlined by the state, demanded that rulers embrace modernity while retaining their indigenous traditions. The former entailed, among others, adoption of metropolitan knowledge to build infrastructure like roads, railways, canals and buildings, adoption of fair governance, and improvement in education and health care (Barr, 1908; Forbes, 1939). The Bhopal Begums combined the best of worlds, the east and the west, thus typifying this ideal.

Bhopal was the second most important Muslim state in British India after Hyderabad, with the ruling elite professing Islam and the laity being predominantly Hindu. The state was founded by an Afghan, Dost Muhammad Khan, in the $18^{\text {th }}$ century, in the politically tumultuous circumstances following

2 Even as the colonial state relied on princely India to realize the modernist agenda, the latter's response to change was complex and multilayered. For a discussion, see, Ian Copland (1997), The Princes of India in the Endgame of Empire, 1917-1947. Cambridge: Cambridge University Press.

3 Scholarly works on mosques of the Indian Subcontinent include among others, Ziauddin Desai (1966) Mosques of India. New Delhi: Government of India, Publications Division; Jose Pereira (2004) The Sacred Architecture of Islam. New Delhi: Aryan Books International; and Fredrick W. Bunce (2008) The Mosques of the Indian Subcontinent: Their Development and Iconography. New Delhi: D.K. Printworld (P) Ltd. 
the demise of the Mughal Badshah (Emperor) Aurangzeb and, thus, had not been under Mughal subjugation. Four illustrious and progressive women rulers ruled Bhopal from 1819 to 1926 in succession. In an age where polity was completely male centric, the Bhopal Begums, their gender notwithstanding were granted the male indigenous elite appellation, Nawab, by the British. The Begums, on their part, amply demonstrated that they were worthy of this distinction as their visionary approach to governance ushered economic and social development in the state and transformed the capital, Bhopal, into a culturally vibrant city.

The four Begums in succession were Nawab Qudsiya Begum (r.181937) the first woman Muslim ruler of an Indian state in British India; Nawab Sikandar Begum (r.1844-68); Nawab Shahjahan Begum (r.1868-1901) and Nawab Sultan Jahan Begum (r.1901-26) ${ }^{4}$. Qudsia Begum first became regent for her daughter Sikandar Begum, who in turn first ruled as regent for her daughter Shah Jehan Begum from 1847 to 1859. Later following Shah Jehan Begum's abdication in favour of her mother, Sikandar Begum became regent for life. Shah Jehan Begum came to power following her mother's demise in 1868 and ruled for the next 33 years when she was succeeded by her daughter Sultan Jahan Begum, the last woman ruler who abdicated power in favour of her youngest son in 1926 (Khan, 2000).

The Bhopal Begums maintained extremely cordial relations first with the British East India Company and, subsequently, the British crown. The relationship was formalized via a treaty in 1818 between the Company and the incumbent ruler, Nawab Nazar Muhammad Khan (r.1816-19) ${ }^{5}$. Relations remained harmonious with the greatest gesture being the support extended to the British during the 1857 uprising by the incumbent ruler, Sikandar Begum. As insurgency spread across Neemuch, Gwalior, Indore and Mhow and threatened Bhopal, the Begum made efficacious arrangements to thwart any form of revolt, the uncooperative stance of her mother, Qudsiya Begum notwithstanding (Bhargava, 1960; Verma, 1984). On July 1, 1858 Sikandar Begum officially declared that peace and order had been restored in the entire state, even as she invited remarks from her subjects that alluded that she was going to convert to Christianity (Verma, 1984). This gesture earned Bhopal the status of a highly favoured loyalist state, with the Begums enjoying political support of the British.

4 The Begums are henceforth referred to in the Paper by their names suffixed by Begum for the sake of brevity.

5 For an account of the early history of Bhopal State, see, William Hough (1845), A Brief History of the Bhopal Principality in Central India. Calcutta: Baptist Mission Press.
Sacralizing The City: The Begums of Bhopal and Their Mosques 

endeavours with equal enthusiasm ${ }^{6}$. Prior to the uprising, Qudsiya Begum commissioned a waterworks system for Bhopal city with British assistance (Ali, 1969). Her successors improved the state's road network, brought in the railways and raised public buildings notably schools and hospitals besides building palaces and gardens for personal use. Under Sultan Jahan Begum's extensive patronage of improvement works, a new cultural landscape of banks, women's clubs, schools, public library, museum and courts, among others, emerged in Bhopal in keeping with the metropolitan ideal ${ }^{7}$. The favoured architectural style was the Indo Saracenic that was regarded and recommended by the colonial state as the most appropriate style for building in princely India post $1857^{\circ}$. In the 1870 s the state was topographically surveyed under the Bhopal and Malwa Survey, while Bhopal city was municipalized in 1903 thus further bolstering the cause of urban improvement.

The Begums' progressive enterprise drew encomium in equal measure from the highest echelons of British authority and their subjects. Even as they enthusiastically implemented the colonial state's modernisation plan, the Begums pursued a parallel Islamic agenda. Their Islamic faith found architectural expression with the building of three Begumi mosques in Bhopal city namely Qudsiya Begum's Jami Masjid (1833); Sikandar Begum's Moti Masjid (1847) and Shahjahan Begum's Taj-ul Masjid (Post-1871). With the rise of nationalism, the royal family's religious activities came under the colonial regime's scrutiny. Shahjahan Begum's second husband, Nawab Siddiq Hasan, a devout orthodox Muslim, was stripped of his titles on the suspicion of being a Wahabi (Sultan Jahan Begum, 1912) ${ }^{9}$. Further, the colonial regime was

6 The Begums were prolific writers whose accounts, describing their development undertakings in detail, were translated into English to reach a wider audience. See, Nawab Shahjahan Begum (1876) Taj-ulIkbal Tarikh Bhopal (The Crown of Prosperity, the History of Bhopal). H. C. Barstow (Tr.) Calcutta: Thacker and Spink; Nawab Sultan Jahan Begum (1912) Gohuri-Ikbal (An Account of My Life).C.H. Payne (Tr.) London: John Murray; and Nawab Sultan Jahan Begam (1926) Hayat-i-Shahjehani: Life of Her Highness the Late Nawab Shahjehan Begum of Bhopal. B. Ghosal (Tr.) Bombay: The Times Press.

7 Some prominent buildings included Minto Hall, Civil Club, Hamidia Khutubkhana (library), Imperial Bank and Edward Museum. The built heritage of the city, including its princely heritage, is regarded as a valuable cultural asset with Bhopal being a member city of the Indian Heritage Cities Network supported by, among others, UNESCO to preserve, manage and use heritage sustainably. For details, see, http://www.ihcn.in/bhopal/194-bhopal. html<Accessed November 2, 2013>

8 For a discussion on the choice of an appropriate architectural style, see, T.R. Metcalf (1989) An Imperial Vision: Indian Architecture and Britain's Raj. London: Faber and Faber.

9 Wahabis were radical followers of Islam who believed in purging Islam of what they regarded as impurities. For a discussion on the Wahabi Movement in India, see, Qeyamuddin Ahmad (1966), The Wahhabi Movement in India. Calcutta: Firma K.L. Mukhopadhyay. 
wary of the support to the Khilafat Movement during the reign of Sultan Jahan Begum $^{10}$.This scrutiny notwithstanding, Bhopal's Masjid-Madrasa (mosqueinstitutions of Islamic learning) spatial ensemble generously spread across all city quarters earned the city the reputation of being an upholder of the Muslim faith in colonial India.

\section{RAISING MOSQUES IN COLONIAL INDIA}

In Muslim ruled Indian Subcontinent, Islam found a dominant representation in the urban landscape, most notably via the Masjid $^{11}$. The delineation of the city's sacred realm came from imperial, sub-imperial and plebeian patronage, as an expression of religious voluntarism and, often by imperial diktat, notably during the reign of Mughal Badshah Shahjahan. The number and types of mosques built during Mughal rule was very large ${ }^{12}$. Typically, mosques ranged from the Jami Masjid (Friday Mosque), a large congregational mosque, epitomizing the mosque par excellence and topping the hierarchy of Islamic sacred space, to mosques forming the focus of an urban quarter and, finally, Muhalla (neighbourhood) level mosques catering to the local resident community. Another mosque type was the Idgah (Mosque dedicated for Eid prayer) located beyond the city walls to accommodate large gatherings of the devout on Eid. A mosque, notably the Jami Masjid, was not simply a place of worship where the devout offered Namaz (Islamic Prayer) five times a day. It transcended its sacred function and acted as a rallying place for the community for socio-cultural interactions. Physically, the spatial envelope of the mosque had evolved over centuries of Muslim dominion in the Subcontinent and was based on the generic Chaukbandiya (held together with a courtyard) plan with a cloister or wall punctuated by gateways defining the central Chauk (courtyard) that was referred to as the Sahn. An ablution pool for Wuzu (ritualistic washing prior to prayer) was provided in the Sahn and the sanctuary stood on the west,

10 For a discussion on the Khilafat Movement in India, see Gail Minualt (1982) The Khilafat Movement: Religious Symbolism and Political Mobilisation in India. Delhi: Oxford University Press and for a discussion on the role of Sultan Jahan Begum, see, Siobhan Lambert-Hurley (2003) 'Princes, Paramountcy and the Politics of Muslim Identity: The Begum of Bhopal on the Indian National Stage, 1901-1926', South Asia: Journal of South Asian Studies, 26(2), 165-191, doi:10.1080/085640032000089753.

11 For the evolution of mosques in the Indian Subcontinent, see Fredrick W. Bunce (2008) The Mosques of the Indian Subcontinent: Their Development and Iconography. New Delhi: D.K. Printworld (P) Ltd.

12 For an architectural account of mosques in Mughal India, see, Ebba Koch (1991) Mughal Architecture: An Outline of Its History and Development (1526-1858).Munich: PrestelVerlag and Catherine B. Asher (1992) Architecture of Mughal India. Cambridge: Cambridge University Press.
Sacralizing The City: The Begums of Bhopal and Their Mosques 
its form outwardly articulated with domes and minarets. Jami Masjids were usually sited in the heart of a city's urban space and their immediate environs sustained bustling bazaars. It was not uncommon to find a mosque built over commercial establishments that stood at street level with the former accessed via flights of steps. Further, mosques acted as urban landmarks with their domes and minarets marking the city skyline.

Even as Mughal rule waned after Badshah Aurangzeb's demise in 1707, the Mughal dynasty continued to remain the wellspring of not only polity but also culture in the indigenous imagination. This perception lent an unequivocal legitimacy to the Mughal Jami Masjid as an archetypical sacred space. Grand Jami Masjids that had been raised by Mughal Badshahs -- Akbar, Shahjahan and Aurangzeb -- were regarded as the ultimate architectural representations of the Islamic faith and served as prototypes not only in their own times but also colonial India (Fig.1a, 1b, 1c).

There was a decline in patronage of congregational mosques, particularly Jami Masjids in the $19^{\text {th }}$ century. Typically mosques tended to be modest even as they subscribed to the Mughal archetype (Fig.2a, 2b). Rise in Christian missionary activity sometimes resulted in mosque precincts hosting theological debates between Maulvis (Muslim clergy) and their Christian counterparts as in Delhi's Jami Masjid (Gupta, 1981) ${ }^{13}$. Further, despite the existence of the Islamic institution of Wakf (Islamic charitable endowment) for upkeep of public buildings including mosques, military engineers were sometimes deputed by the Company to clean and repair mosques. Bishop Heber reported that Delhi's Jami Masjid was maintained through a grant provided by the British (Heber, 1829) ${ }^{14}$.

During the 1857 uprising, several mosques across the north and central parts of India served the revolting indigenes by doubling up as meeting places and, were subsequently transformed into battle sites. Bhopal's Mankashah and Madar Ali Mahm Mosque was used by the city's disgruntled indigenes

13 Even as these inter-faith deliberations did not upset communal harmony in the city, they did cause resentment among Muslim scholars. Shah Abdul Aziz, a leading $19^{\text {th }}$ century Islamic scholar of Delhi, declared that Muslim administration had been rendered powerless and the city was being ruled by Christians. See, Mushir-ulHaq (1995) Shah Abdul Aziz, His Life and Times: A Study of Indian Muslims' Attitude to the British in the Early $19^{\text {th }}$ century. Lahore: Institute of Islamic Culture.

14 Gupta has stated that the funds for the Jami Masjid's repair were provided by the Wakf while repairs were carried out by a Company deputed military engineer. See, Narayani Gupta (1981) Delhi Between Two Empires: 1803-1931 - Society, Govt. \& Urban Growth. Delhi: Oxford University Press. 
Figure1a: Badshah Akbar's Jami Masjid, Fathepur Sikri: View from Southwest. (Image Courtesy: ASI, U.P. Vol. 40 1932-34; 6127)

Figure1b: Badshah Shahjahan's Jami Masjid, Delhi: View of Sahn from entrance gateway. (Image Courtesy: ASI, Delhi, Vol. 1 1954-55; 1959-61, 1493/55)

Figure 1c: Badshah Aurangzeb's Badshahi Masjid, Lahore: View from Hazuri Bagh. (Image Courtesy: ASI, Punjab, Vol. 45 1930-31, 2801)

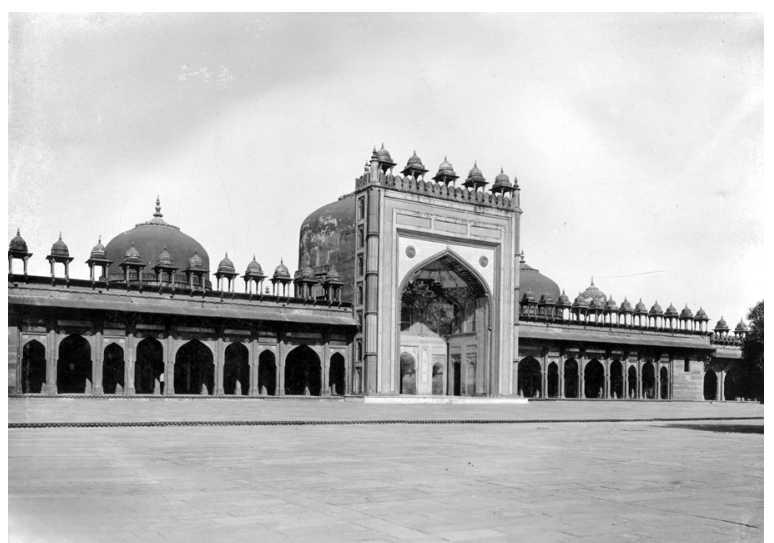

Sacralizing The City: The Begums of Bhopal and Their Mosques
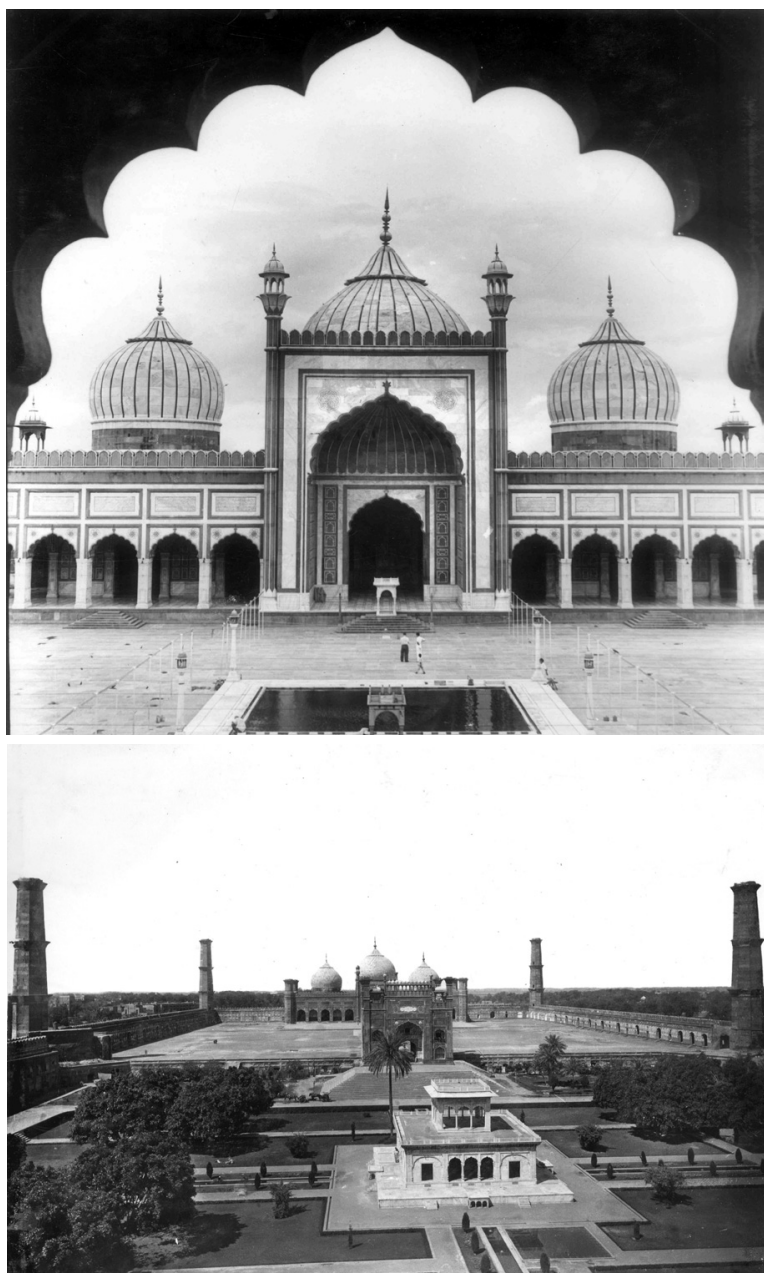
Sharma, J.P..

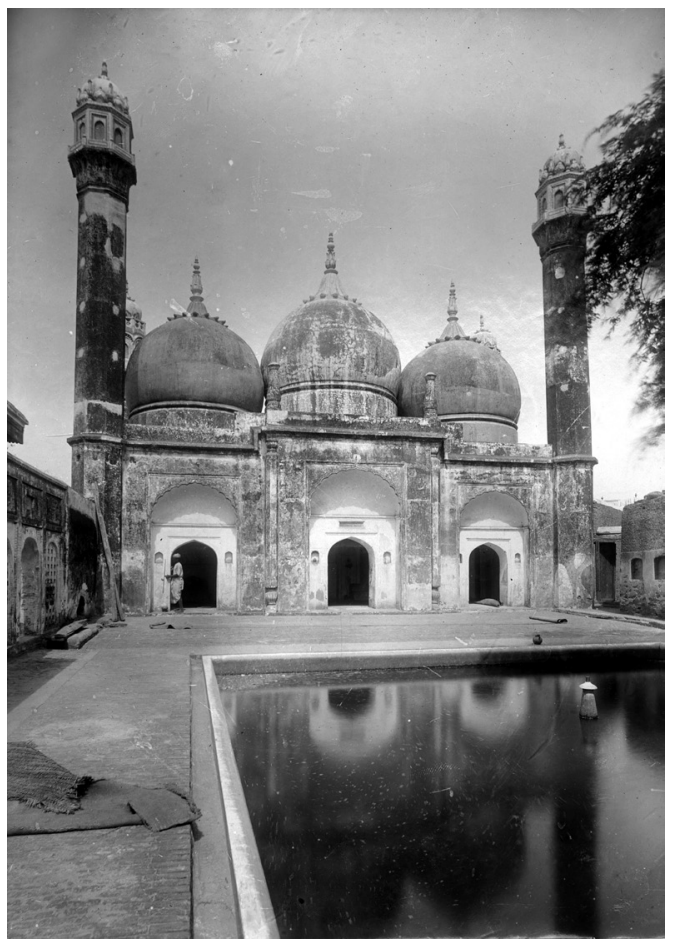

Left:

Figure 2a: Serai Wali Masjid, Kerana, Muzaffarnagar District, U.P: View from East (Image Courtesy: ASI, U.P. Vol. 17 1911-13, 2431)

Right (Opposite page):

Figure 2b: Mosque of Makka Darzi, Khairabad, Sitapur: General View from Northeast (Image Courtesy: ASI, U.P., Vol. 17 1911-13, 2379)

to assemble and strategize even as Sikandar Begum ensured that unrest was contained (Verma, 1984) ${ }^{15}$.

However, this was not the case elsewhere, as in Delhi the city mosques became spaces that abetted unrest ${ }^{16}$. Delhi's Fathehpuri Masjid was occupied by rebelling troops, while the standard of Jihad (Islamic holy war / struggle) was raised in the Jami Masjid that offered refuge to the city's Muslims and turned into a battleground on September 14, 1857 after British forces entered the walled city and advanced to the mosque (Jivanlal, 1898).

The British dealt a blow to the uprising and emerged victorious. Following a retrospection of the 1857 events, the colonial state declared Muslims to be the

15 For an account of the Begum's reign, see S.C. Mukhopadhyaya (1869) The Career of an Indian Princess-The Late Begum Sikandar of Bhopal. Calcutta: Anglo-Sanskrit Press.

16 This was by no means only a colonial phenomenon as was witnessed in post colonial India in 1987 when Delhi's Jami Masjid was appropriated as a political space and closed by its Imam (cleric) for worship. For a discussion, see, Hilal Ahmed (2013) 'Mosque as Monument: The Afterlives of Jama Masjid and the Political Memories of a Royal Muslim Past', South Asian Studies, 29:1, 51-59, doi:10.1080/02666030.2013.772814 


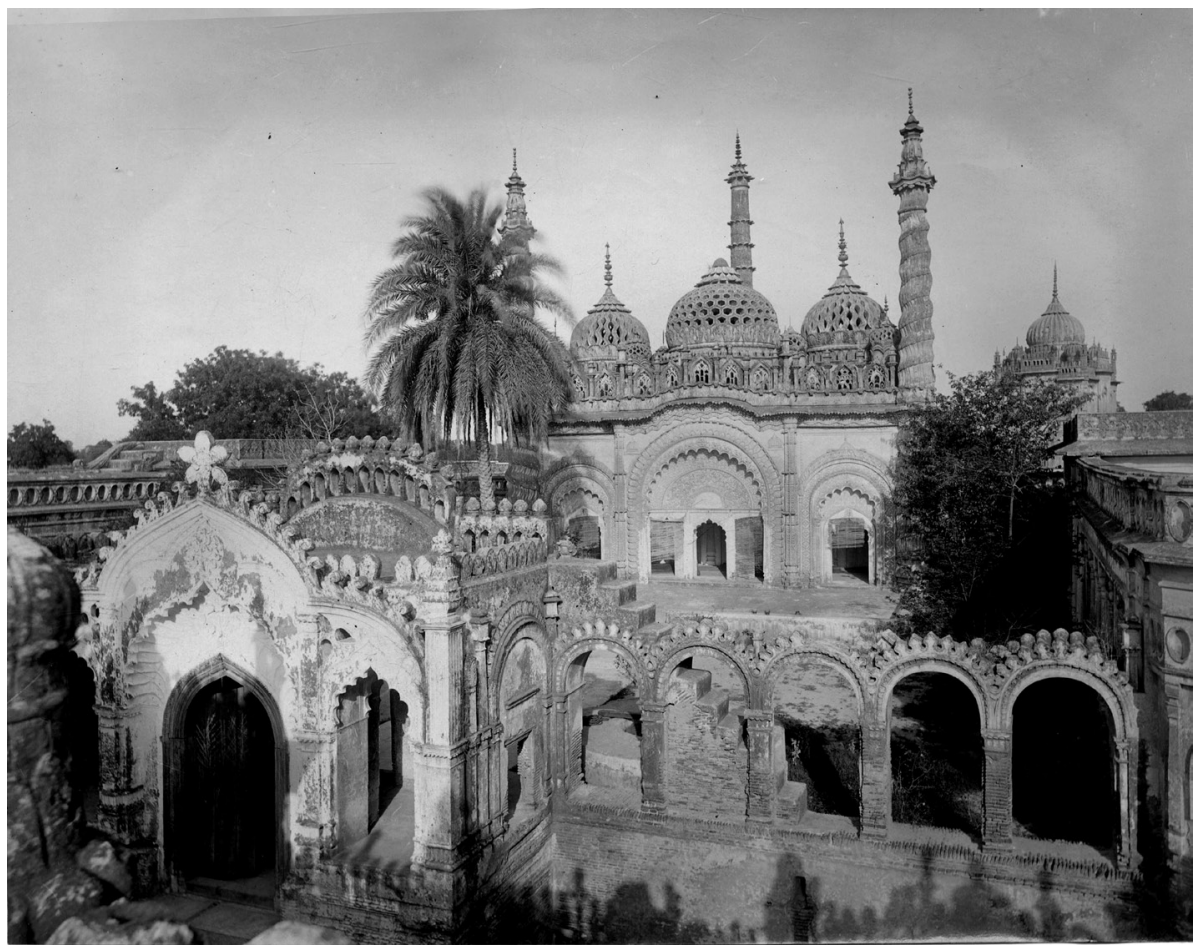

Sacralizing The City: The Begums of Bhopal and Their Mosques

perpetrators of the uprising ${ }^{17}$. This charge was not confined to the community but also extended to its mosques with Jami Masjids and Idgahs coming under state scrutiny. Regarded as spaces likely to foment future trouble, the colonial state sanctioned the desecration of their premises through demolition, military occupation and auction. Mosques in Delhi, one of the major centres of the uprising, provided a textbook case for the treatment of mosques that was centered on defiling their religious sanctity (Gupta, 1981) (Fig.3a, 3b, 3c).

The devout, deprived of their place of worship, petitioned the British government for the release of mosques in Delhi and elsewhere. One influential petitioner was Sikandar Begum who urged the colonial state for the restoration of Delhi's Jami Masjid to worshippers (Khan, 2000) ${ }^{18}$. Muslims perceived the

17 For a discussion on the community in the backdrop of the uprising, see Francis Robinson (1993) 'The Muslims of Upper India and the shock of the Mutiny-Rustkhez-ibeja', in Mushirul Hasan and Narayani Gupta (Ed.) India's Colonial Encounter: Essays in memory of Eric Stokes. Delhi: Manohar, 183-99 and K. M. Ashraf (2007) 'Muslim Revivalists and the Revolt of 1857', in P.C. Joshi (Ed.) Rebellion 1857. Delhi: National Book Trust, 78-111.

18 Delhi's Jami Masjid and Fatehpuri Masjid were restored to the Muslim community in 1862 and 1877 respectively following several political consultations. 
desecration of mosques, traditionally regarded as the epicentre of Islam, as an assault on their faith by the colonial regime. Indeed, in the community's worldview, the post uprising era is associated far more strongly with colonial acts of desecration of mosques than by endeavours of patrons like the Bhopal Begums to raise new ones.

\section{BHOPAL'S BEGUMI MASJIDS}

The Begums were devout Muslims who adhered to the orthodox Deobandi version of Islam (Khan, 2000) ${ }^{19}$. Barring Shahjahan Begum, the other three Begums comported themselves in a simple manner, shunning all ostentatious trappings that princely India usually took up as matter of habit. Their proclivity towards Islam was highly personal and diverse. Qudsiya Begum and Sultan Jahan Begum held a strong personal religious conviction. Sikandar Begum relied on religion as part of statecraft (Khan, 2000). She was the first ruler from the Indian Subcontinent to perform Haj (pilgrimage to Mecca), an event that she recorded for posterity as a travelogue in Urdu, A Pilgrimage to Mecca $^{20}$. Shahjahan Begum had a somewhat ambiguous attitude towards Islam in her early years. Following her second matrimonial alliance with Nawab Siddiq Hasan, she gave up some of her seemingly un-Islamic habits, and also took up the Purdah (veil) that both her forbearers' had given up for reasons of practicality (Khan, 2000). Further, she extensively patronized the cause of Islam and, Bhopal state was not the sole beneficiary of her patronage as she funded the building of a mosque in the town of Woking, Surrey, in Britain in 1887 (Ansari, 2002). The Begums received the support of the Ulema (Islamic Clerics) with both sharing a cordial relationship. This environment of mutual respect gave fillip to religious activities manifest via construction of mosques prompting the following remark from Louis Rousselet that 'Each District has its mosque, which sometimes is merely a little paved yard, (...)' and sometimes is '(...) an imposing edifice of grand proportions surmounted by elegant minarets' (Rousselet, 1882:451). Bhopal's large corpus of mosques included the three Begumi Masjids, each proclaiming the might of Islam in predominantly Hindu Bhopal, and dominating its respective city quarter through sheer physical presence as well as acting as an important element in urban space.

19 Deobandi Islam was a revivalist movement that emerged in South Asia during colonial rule and was based at the Islamic seminary, Darul Uloom at Deoband. For a history of the rise of Deobandi Islam, see Barbara Metcalf (1982) Islamic Revival in British India: Deoband, 1860-1900. Princeton: Princeton University Press.

20 For an account of the pilgrimage, see Nawab Sikandar Begum (1870) A Pilgrimage to Mecca by The Nawab Sikandar Begum of Bhopal. Mrs. Willoughby-Osborne (Tr.) \& (Ed.) London: W.M.H. Allen and Company. 
Figure 3a: Jami

Masjid, Delhi: Major city landmark (Image Courtesy: ASI, Punjab, Vol. 6 1904-5, P41).

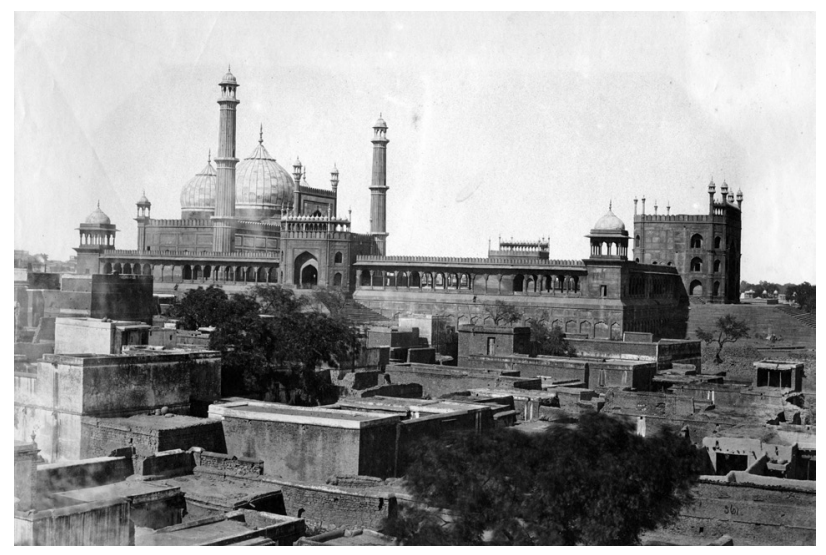

Figure 3b: Jami Masjid, Delhi: Post 1857

following demolition of its environs. (Image Courtesy: ASI, Punjab, Vol. 1 1902-3, 72)
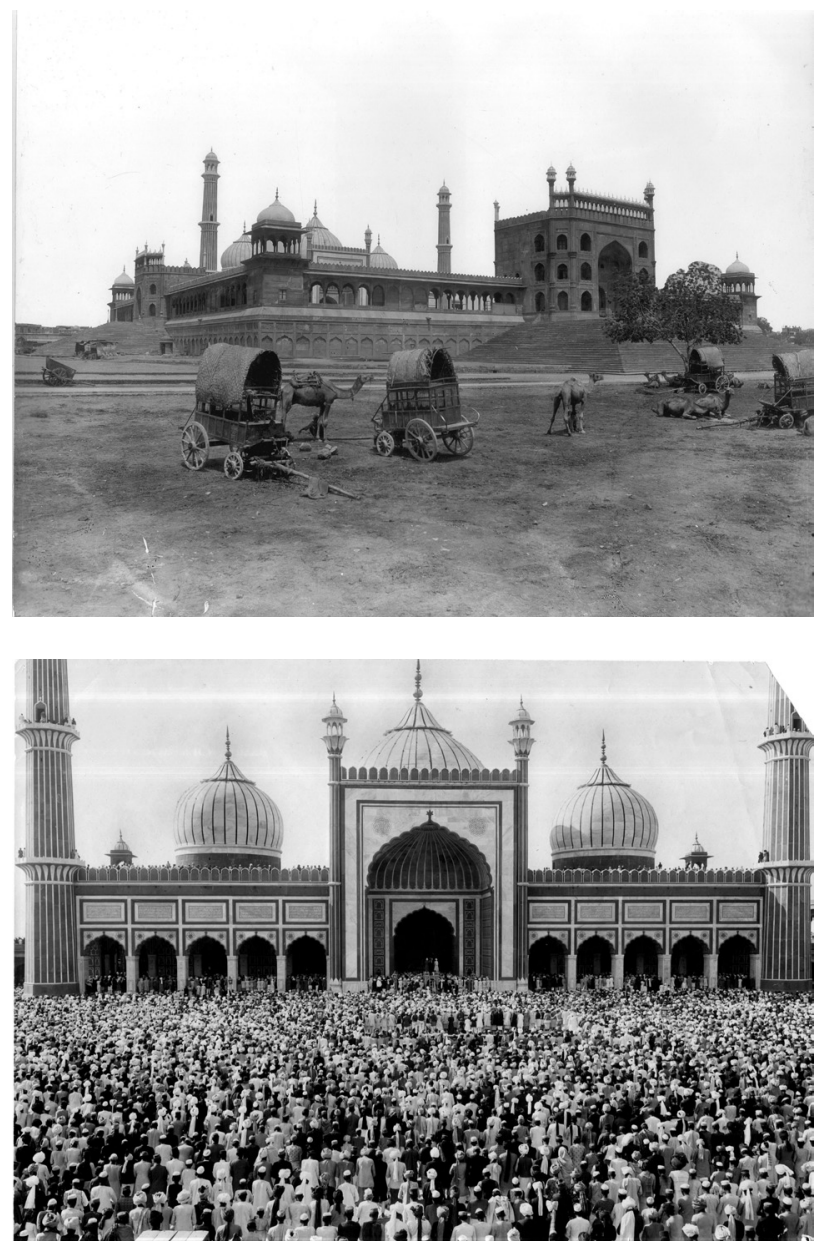

Sacralizing The City: The Begums of Bhopal and Their Mosques
Figure 3c: Jami Masjid, Delhi: Post 1857 following restoration to the Muslims (Image Courtesy: ASI, Delhi, Vol. ? P. 73-004). 
Sharma, J.P.

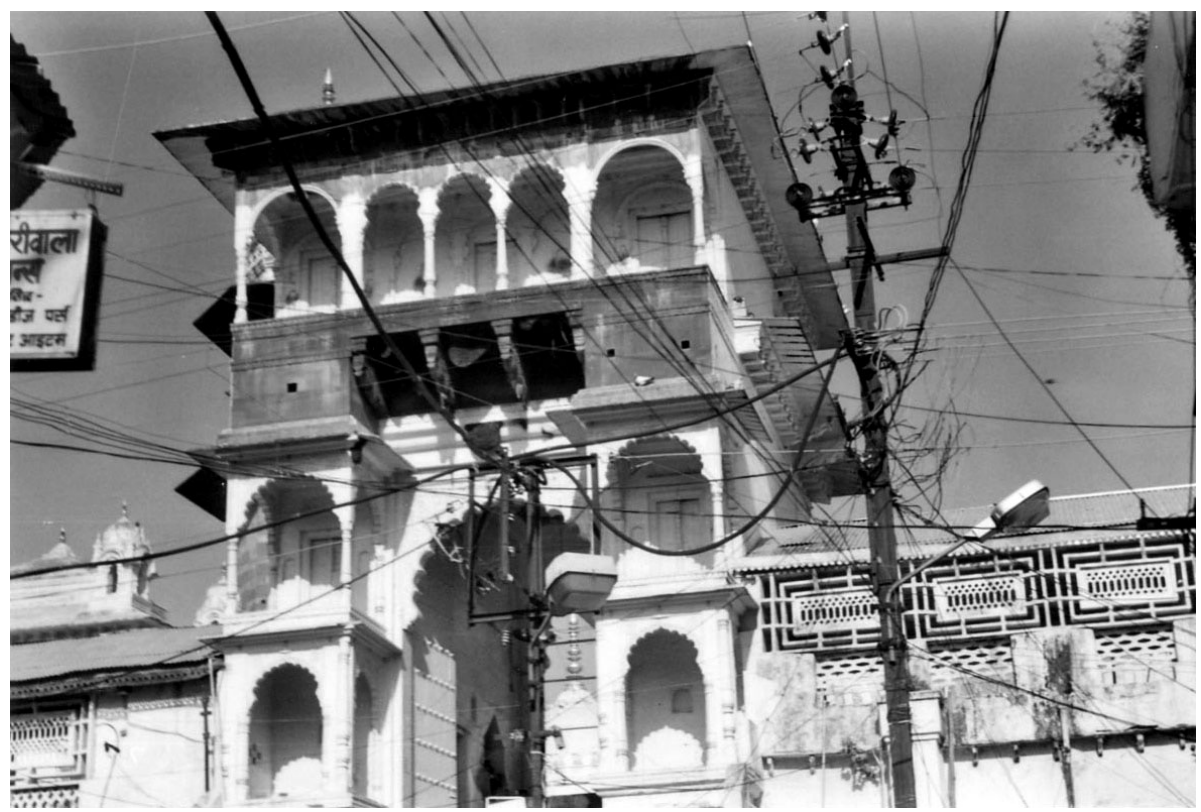

Figure 4: Nawab Qudsiya Begum's Jami Masjid, Bhopal: Entrance Gateway (Image Courtesy: Commissioner, Archaeology, Archives and Museums, Government of Madhya Pradesh, Bhopal)

\section{Qudsiya Begum's Jami Masjid}

The Jami Masjid was built in 1833 in the walled city of Bhopal, Shahr-i-Khas (special city). The mosque, subscribing to the archetypical layout, stood on a high plinth with shops at the street level, accessed via three large gateways that opened into the Sahn bordered intermittently by rooms and colonnades (Fig. 4). The sanctuary was crowned with three rather shallow domes with two attached bulky minarets finished in stone (Santelli et al. 2010). The mosque was built at the intersection of two cardinally oriented, pre-existing bazaar streets, the intersection being called Jami Masjid Chauk (Square). The patron widened the junction of the east-west and north-south bazaars to locate the mosque in the centre of the city (Sobti, 1994) ${ }^{21}$. Further, linkages were established between the Jami Masjid, via the bazaars, to the city gates Peer Darwaza and Itwara Darwaza in the east-west direction and, Jummerati Darwaza and Ibrahimpura in the north-south direction. Its location in the midst of a commercial area made the Jami Masjid a hub of activities beyond the divine and it asserted its

21 Manu P. Sobti has produced a detailed architectural analysis of Bhopal's Jami Masjid and Moti Masjid among other Begumi buildings as part of his undergraduate architectural thesis. 
presence both physically and symbolically amidst the modest bazaar structures in its immediate environs. Shahjahan Begum's Taj-ul-Ikbal Tarikh Bhopal (henceforth referred to as Tarikh Bhopal) mentioned that 'There are upward of 100 stone and brick mosques in this city. The finest is the Jama Masjid built by the Nawab Kudsia Begam (...)' (Shahjahan Begum, 1876:227). Rousselet described it as a 'fine edifice, built in a simple style' and remarked that its approach constituted the '(...) most interesting part of the capital. It is there that the jewelers' shops, the mercers', the pastry cooks', the armourers, and the cafes are assembled' (Rousselet, 1882:451).

\section{Sikandar Begum's Moti Masjid}

Moti Masjid was built in 1847 to the southwest of the Jami Masjid beyond the confines of the walled city. It was modelled on Delhi's Jami Masjid, built by Badshah Shahjahan in the $17^{\text {th }}$ century, borrowing not only from its layout and façade articulation elements but also adopting the same material, red sandstone and white marble (Fig.5a, 5b). The mosque was built on the shorter, eastern edge of a large quadrangular Maidan (open urban space) that had a number of Khirni trees giving it the name Khirniwala Maidan ${ }^{22}$. With its sanctuary defining the Maidan edge, the mosque was accessed via a steep flight of steps from the east and had a large garden forecourt. Its positioning at the head of Khirniwala Maidan made it the originator of Bhopal's new royal enclave with imperial and sub-imperial palace complexes notably Sikandar Begum's Moti Mahal and others like Shaukat Mahal, Zeenat Mahal, Humayun Manzil and Hamid Manzil. These structures were built along the longer edges of the Maidan that was finally articulated as two courts, the larger one on the east designated as the public quadrangle while the smaller one as a private open space (Sobti,1994). The Maidan was the receptacle of all forms of imperial and sub imperial movement, ceremonial or otherwise, and directed attention on Moti Masjid that acted as the fulcrum of a new urban order where two axes met, one governed by Islamic diktat to face Mecca in the west and the other skewed to align the mosque with the Maidan (Sobti, 1994). Moti Masjid, still unfinished at the time of writing of Tarikh Bhopal, invited praise from the writer, who was also its patron's daughter and successor, who described it as '(...) a lofty and handsome building. There are far larger cities which cannot boast a mosque to compare with either of the above' (Shahjahan Begum, 1876:227). Rousselet remarked that the Moti Masjid '(...) would be considered a grand monument for any period and in any country' (Rousselet, 1882:452).

22 Khirini is a small tree with edible fruit found commonly across Central India with Botanical Name Manilkara Hexandra.
Sacralizing The City: The Begums of Bhopal and Their Mosques 
Sharma, J.P..

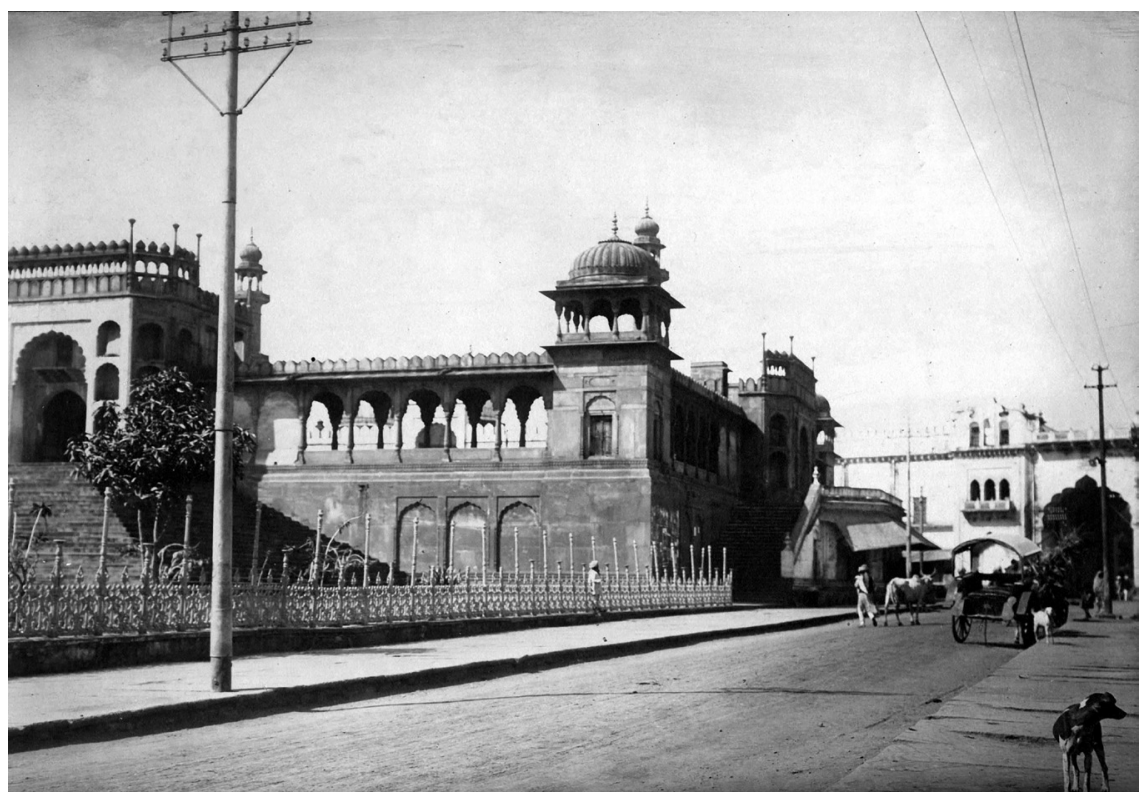

Figure 5a: Nawab Sikandar Begum's Moti Masjid: Partial view of Eastern Gateway with gateway to Khirniwala Maidan seen in the distance (Image Courtesy: Commissioner, Archaeology, Archives and Museums, Government of Madhya Pradesh, Bhopal)

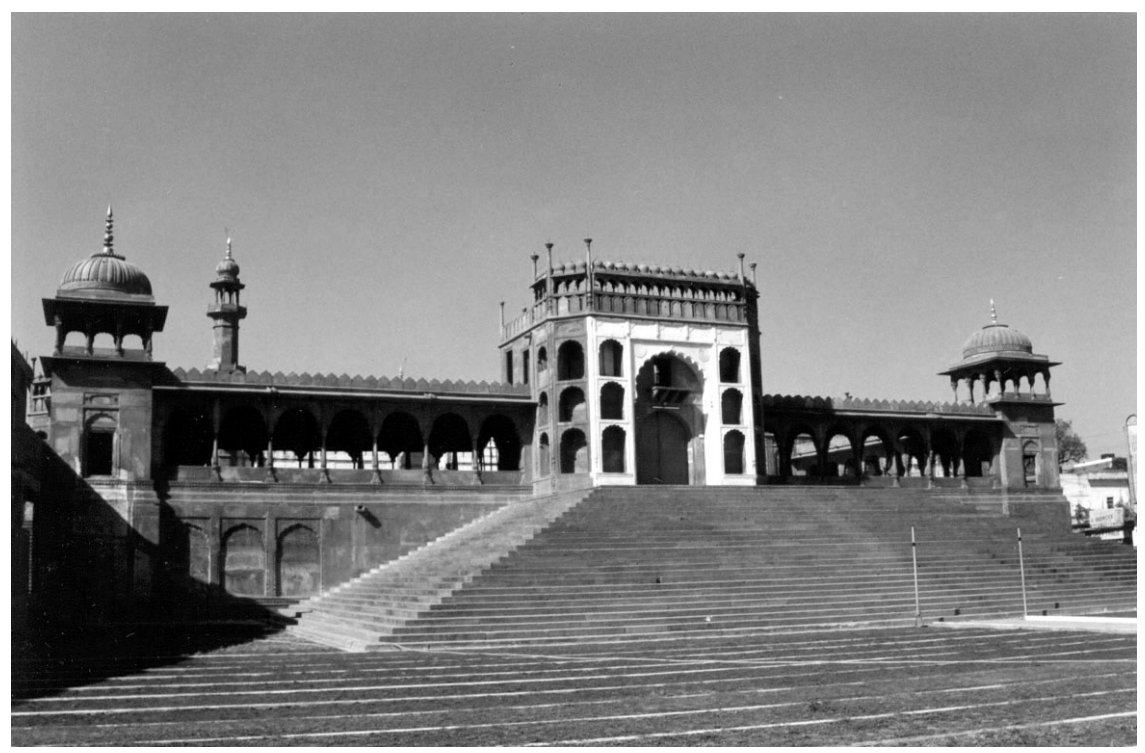

Figure 5b: Nawab Sikandar Begum's Moti Masjid: Eastern Gateway and garden forecourt (Image Courtesy: Commissioner, Archaeology, Archives and Museums, Government of Madhya Pradesh, Bhopal). 


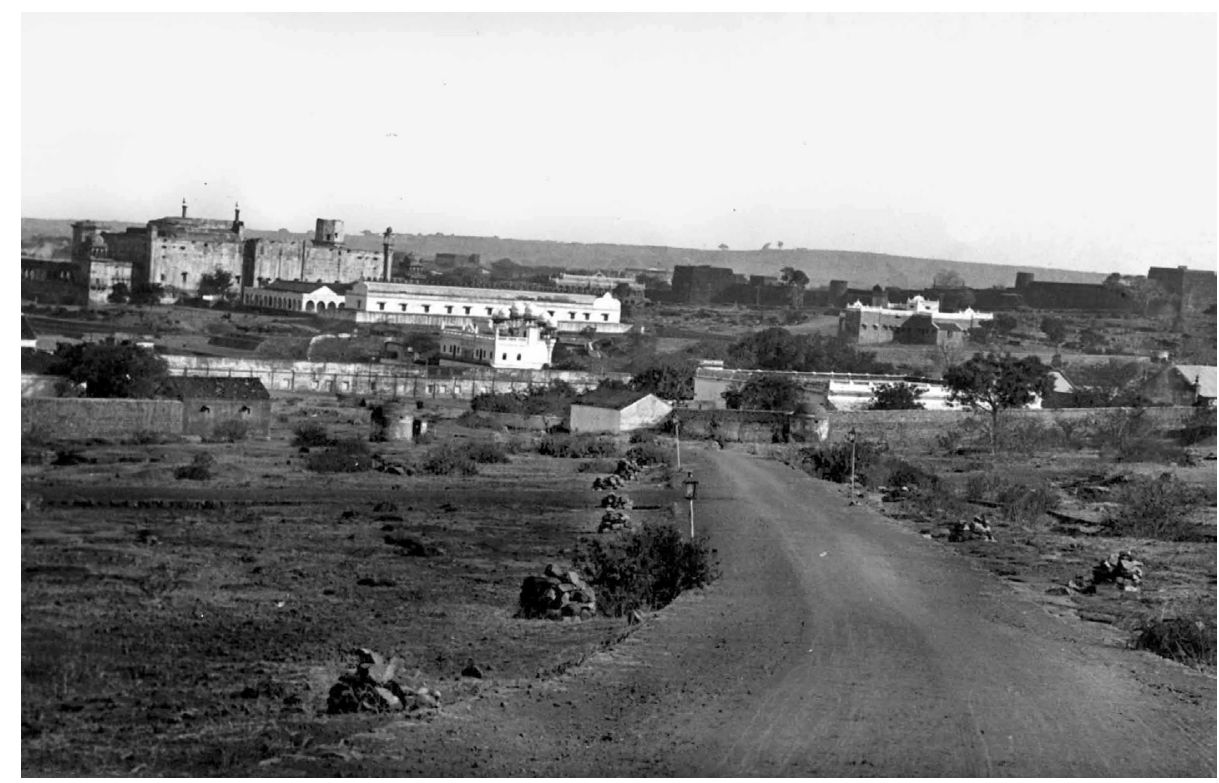

Sacralizing The City: The Begums of Bhopal and Their Mosques

Figure 6: Nawab Sultan Jahan Begum's Shahjahanabad: View of the imperial suburb with Tajul Masjid under construction Courtesy: Commissioner, Archaeology, Archives and Museums, Government of Madhya Pradesh, Bhopal.

\section{SHAHJAHAN BEGUM'S TAJ-UL MASJID}

Taj-ul Masjid was built in the newly laid out walled suburb named Bhopal Shahjahanabad after Shahjahan Begum. Shahjahanabad was laid out beginning 1874 northwest of the city and contained public institutions like schools, serais (rest houses), library and mosques besides the patron's palaces notably Taj Mahal. The entire spatial ensemble was planned around three water bodies, Munshi Hussain Talab, Noor Mahal Talab and Motia Talab. While the exact date of the initiation of the construction of Taj-ul Masjid is not clear, it would not be inaccurate to suggest that the venture was initiated after 1871 when Shahjahan Begum turned towards Islam influenced by her second spouse's religious zeal ${ }^{23}$. Taj-ul Masjid, designated as an Idgah, was built on a hillock at the highest elevation in the suburb and was envisioned to be one of the grandest mosques in the Indian Subcontinent (Fig.6) (Sharma and Ali, 1980) ${ }^{24}$. Its constuction

23 The repercussions of this matrimonial alliance were significant both personally and politically. For an account, see Metcalf, Barbara (2011) 'Islam and Power in Colonial India: The Making and Unmaking of a Muslim Princess', The American Historical Review, 116(1), 1-30.

24 Bhopal already had a Jami Masjid and with a city having only one designated Friday Mosque, it is reasonable to accept that Taj-ul Masjid was envisioned as an Idgah. 

the divine with Bhopal being declared as a centre of Islam (Shahjahan Begum, 1876) and its patron positioned as a '(...) highly visible protector and patron of Islam' (Metcalf, 2011:16). The mosque exceeded its imperial predecessors in terms of size and, unlike the Jami Masjid, it dominated an urban landscape of gardens, water bodies, imperial palaces and public institutions and further, unlike Moti Masjid it was not positioned to act as an urban pivot. Taj-ul Masjid was under construction when its patron passed away in 1901 and construction was later supervised by Sultan Jahan Begum. Gordon Sanderson visited the site in 1913 and observed that the '(...) plan and elevation (...) were prepared by Muhammad Raushan, a Delhi draftsmen (...)' (Sanderson, 1913:11) ${ }^{25}$. It was raised on a high plinth and stood on the edge of Motia Talab that doubled as its ablution reservoir accommodating around 10,000 persons at one time (Qureshi, 1969).

The design, while subscribing to the Mughal archetype both in form and material, was also innovative in that it made provision for women worshippers via the 'Zanana gallery', 'commodious Zanana chapels' at either end and a 'mezzanine floor at each end of the mosque, near the minars' (Fig.7a, 7b) (Sanderson, 1913:12) 26 $^{2}$ The Zenana (women's) space was further sub divided to cater to differences in rank of their users ranging from the Begums to noble ladies to laity (Sharma and Ali, 1980). Another certain first in mosque construction in the Subcontinent, as recorded by Sanderson, was the use of reinforced concrete in the twin minarets (Sanderson, 1913). Further, Sultan Jahan Begum noted that 'The crystal slabs, designed for the floor, were prepared in England at a cost of seven lakhs of rupees; but as their polished surfaces would have reflected the forms of the worshippers, their use in the mosque was forbidden. When finished, the Taj-ul-masjid will rank amongst the finest buildings in the world' (Sultan Jahan Begum, 1912:198-199).

The precinct also had a school for Arabic education with a library, research centre and a place of lodging for scholars and students (Qureshi, 1969). Sanderson wrote that it would be difficult for his English compatriots

25 In the early $20^{\text {th }}$ century the British government commissioned a survey of 'Types of Modern Indian Buildings' with Gordon Sanderson of Archaeological Survey of India deputed to conduct it. Sanderson's survey covered select cities including Bhopal where two mosques, Taj-ul Masjid and that of Kulsum Bi, were identified for inclusion.

26 Spatial provision for the Zenana (women) was hardly the norm in the Subcontinent as women prayed from the confines of their domestic space. While Jami Masjids at Sarkhej and Champaner in Gujarat provided enclosures for women, in Bijapur separate mosques were built for women. Taj-ul Masjid certainly broke new ground in terms of innovative design besides acting as a beacon of women's rights considering the patron's and her successor's tireless initiatives to improve the condition of women. 


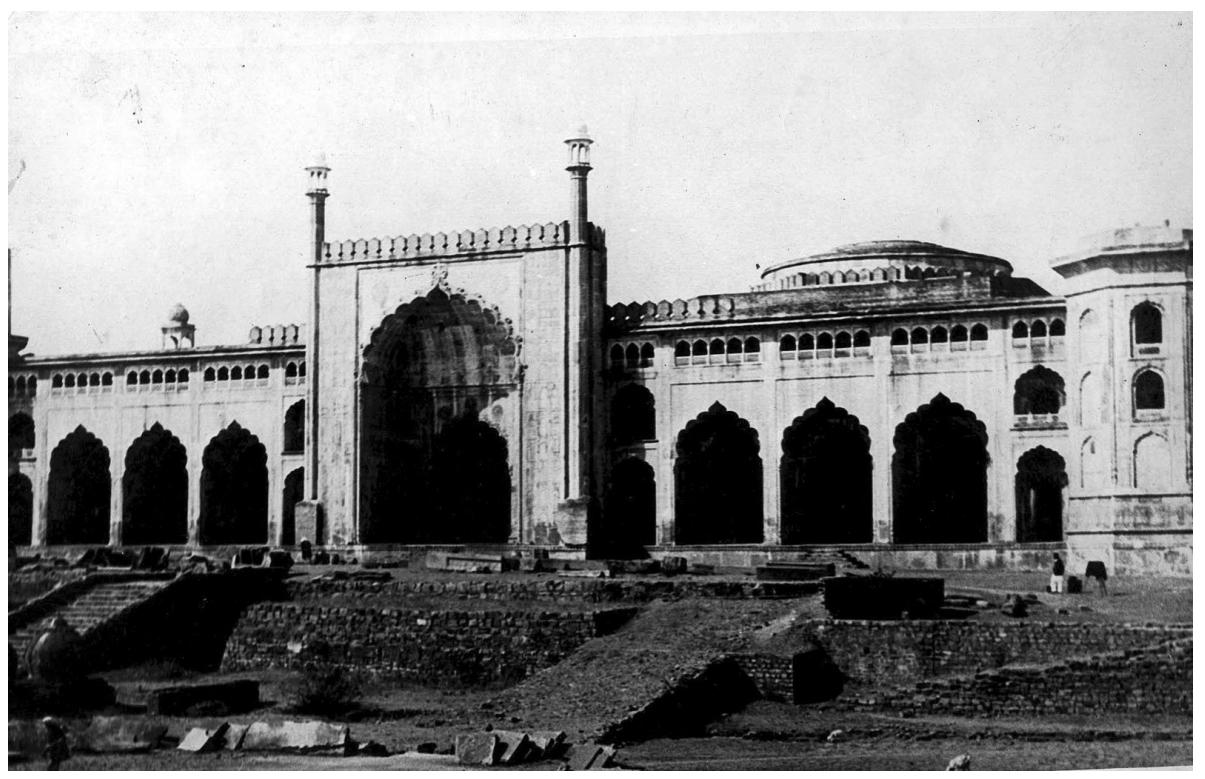

Sacralizing The City: The Begums of Bhopal and Their Mosques

Figure 7a: Taj-ul Masjid, Bhopal: Mosque under construction. (Image Courtesy: Commissioner, Archaeology, Archives and Museums, Government of Madhya Pradesh, Bhopal)

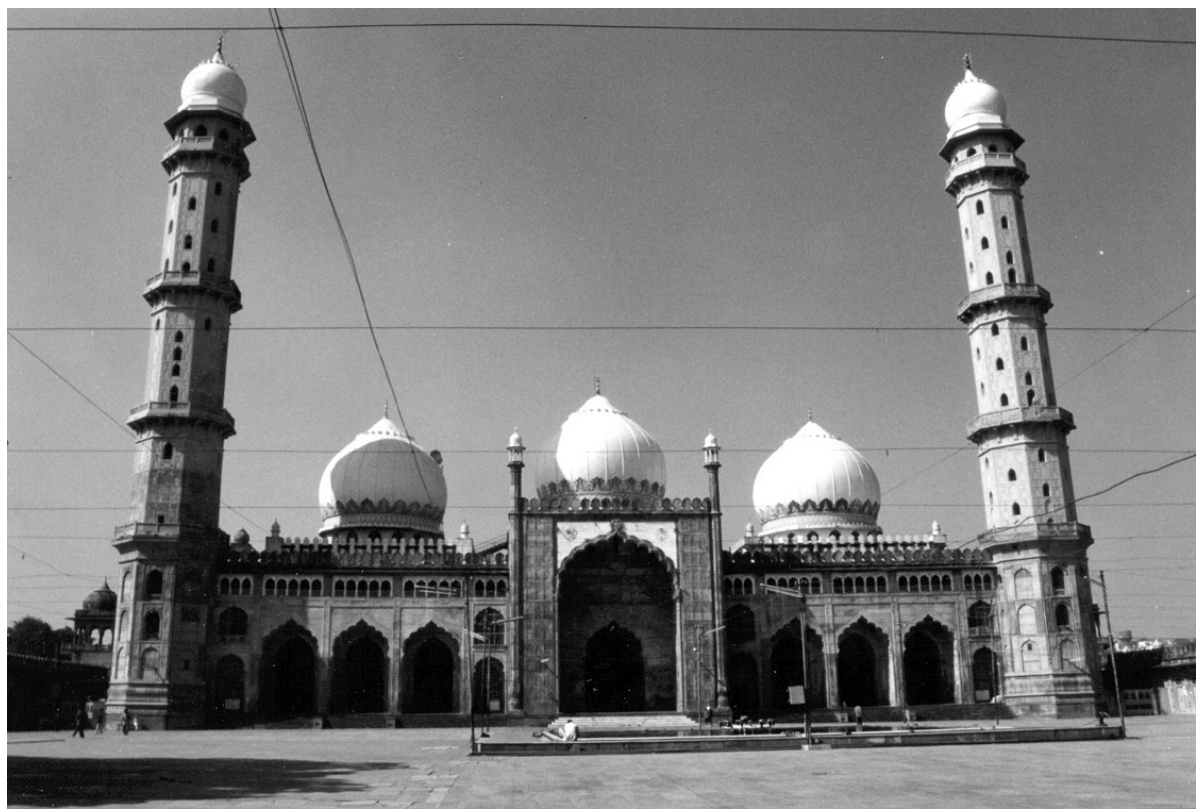

Figure 7b: Taj-ul Masjid, Bhopal: Sahn with Sanctuary. (Image Courtesy: Commissioner, Archaeology, Archives and Museums, Government of Madhya Pradesh, Bhopal) 
to not admire Taj-ul Masjid 'the largest mosque in modern India' that '(...) will be a close rival to the Jami Masjid at Delhi (...)' (Sanderson, 1913:11\&34). Clearly, the religious precinct was far from finished when Sanderson visited it. The project remained unfinished, in all likelihood owing to paucity of funds, for decades during the rule of successive Bhopal Nawabs and later following independence. Qureshi's 1969 account of the mosque ends with an appeal to complete the Begum's unrealized dream in its entirety including its environs (Qureshi, 1969)27.

The Begums' mosque building endeavours permit one to look beyond the tangible sphere of architecture to a more abstract and complex underlayer of multiple meanings. The building of the mosques acquires greater significance when examined against the backdrop of waning Mughal authority in the $18^{\text {th }}$ century. The Mughal legacy perceived as symbolizing both authority and opulence had a pan-Indian appeal even in the post Mughal era (Metcalf, 2011). That the Bhopal Begums regarded the Mughals as role models can be gauged equally creditably from their writings like Sultan Jahan Begum's Gohur-i-Ikbal and from their personal comport, beginning with their names that bordered on the unfeminine and extending to their architectural ventures ${ }^{28}$. As Bhopal state acquired the status of being the second most important princely state of the British Raj, its rulers, the Begums, sought to position themselves as claimants of the illustrious north Indian Muslim imperial legacy (Archambault, 2013).

As the myth of Mughal invincibility faltered and was ultimately shattered in 1857, the void that resulted, afforded the Begums an opportunity to stake claim as legitimate and seamless inheritors of the Mughal legacy. This included taking charge of the Mughal legacy of stewardship of Islam, in the post uprising era, when the colonial regime's anti-Muslim and anti-mosque sentiment prevailed. The Begumi mosques' subscription to the Mughal architectural archetype attested the patrons' intent to forcefully assert their religious identity via the well established Mughal design vocabulary. Sikandar Begum's Moti Masjid was patterned on Delhi's Jami Masjid and was built ten years prior to the uprising. Further, her engagement with Delhi's Jami Masjid post 1857 can be read as an act of atonement for the support she had extended to the British during the insurrection. Touring Delhi in 1861, the Begum visited the city's

27 Plans to complete the mosque precinct were undertaken in the 1970s and the project was completed a decade later with a ceremony marking its opening. From 1947 to 2001, the mosque continuously hosted an annual three day Aalmi Tablighi Ijtima(World Islamic Congregation) that attracted Muslims from around the world.

28 Sultan Jahan Begum compared her grandmother, Sikandar Begum, to Badshah Akbar and likened her mother's building enterprise to that of her Mughal namesake Badshah Shahjahan. Indeed, the Begums' names, i.e., Sikandar, Shahjahan and Sultan Jahan, were not among the common names given to female Muslims. Shahjahan Begum named her newly laid out city quarter, Shahjahanabad, after $17^{\text {th }}$ century Mughal Delhi and her palace complex as Taj Mahal, after Badshah Shahjahan's most celebrated funerary complex for his spouse. 
prominent religious sites including Dargahs (final resting places of Sufi Saints held in veneration), Mughal Qila (Palace-Fort) and mosques in the walled city including Zinat-ul Masjid and Jami Masjid ${ }^{29}$.

Both Tarikh Bhopal and Gohur-i-Ikbal record the Begum's visit to Delhi's Jami Masjid. The former stated that 'The gates of the mosque were closed, but the English officers had them opened (...)' (Shahjahan Begum, 1876:91) ${ }^{30}$. The latter citing an 1862 communication from Captain Hutchinson, Political Agent of Bhopal, stated that 'it was at the request of Nawab Sikandar Begam that it was once more opened to the public. (...) on its being reopened the Begam was the first person to enter and perform her prayers' (Sultan Jahan Begum, 1912:11). Khan further attests this by stating, rather theatrically though, that the Begum ' (...) persuaded the British to re-open the famous Juma Masjid in Delhi which they had seized after the Mutiny. Sikandar went down on her knees and personally washed the floors of the Juma Masjid courtyard' (Khan, 2000: 224) ${ }^{31}$. These gestures undoubtedly helped the Begum regain lost ground owing to 1857 and bolstered her image as an upholder of Islam. Further, Shahjahan Begum's conception of Taj-ul Masjid as a monumental sacred precinct and her extensive patronage of religious institutions marked, in equal measure, the perfect coming together of 'the imperial program and the Islamic program' that had taken a pivotal position following her reawakening towards Islam (Metcalf, 2011:16).

The Begums' patronage of the mosques lent Bhopal a unique distinction of having three grand imperial mosques, Jami Masjid, Moti Masjid and Taj-ul Masjid, occupying and sacralizing their respective city quarters, Shahr-i-Khas, Khirniwala Maidan precinct and Bhopal Shahjahanabad. This created three significant and competing, sacred domains in one city, a somewhat unusual scenario since mosques in Muslim ruled Indian Subcontinent, including those in Mughal cities, collectively subscribed to the established hierarchy whereby the Jami Masjid was accorded primary status as a sacred realm. Indeed the Jami Masjid did not vie with other city mosques as a religious institution. Further,

29 Archambault has argued that the Begum's tour was an exercise in projecting both herself and Bhopal state as a dominant political and cultural force in post 1857 Indian Subcontinent. See, Hannah L. Archambault (2013), 'Becoming Mughal in the Nineteenth Century: The Case of the Bhopal Princely State', South Asia: Journal of South Asian Studies, 1-17, doi: 10.1080/00856401.2013.788465.

30 British retribution post 1857 resulted in recommendations ranging from demolition of Delhi's Jami Masjid to its conversion into a church. These proposals were not executed and the precinct was occupied by the British army that moved out in 1862. The Begum's second visit to Delhi was by train in 1866 by which time the mosque had been handed back to the Muslims for worship.

31 Khan does not present any evidence for Sikandar Begum 's action, but it is rather appealing to believe that he speaks with some veracity, as he is a descendant of the Bhopal royal family and therefore privy to information, particularly oral, not in the public domain.
Sacralizing The City: The Begums of Bhopal and Their Mosques 
it was also hardly the norm for an Idgah to architecturally overpower a Jami Masjid as Bhopal's Taj-ul Masjid, an Idgah, was envisioned to do despite its physical distancing from the city's Jami Masjid. Lack of substantive evidence notwithstanding, it is rather tempting to suggest, against the backdrop of the Begums' far from cordial filial relationships, that while unanimously staking claim to the Mughal religious legacy, the Begums, were competing with each other to sacralize Bhopal.

\section{CONCLUDING REMARKS}

The Begumi Masjids were subjects of both textual and visual representation, with the Begums themselves never failing to mention them in their accounts. In terms of visual representation the mosques were photographed in the late $19^{\text {th }}$ and early $20^{\text {th }}$ centuries by leading photographers of the times including Bourne and Shephard, J. R. Sheffield and Lala Deen Dayal. The mosques completely justified Shahjahan Begum's remark about Bhopal that anyone who has seen the ' $(. .$.$) collection of mosques, colleges and learned doctors of Islam (...) and$ has beheld (...) the crowded state of the mosques (...) must acknowledge that there still remains in this city a sure foundation of the faith; (...)' (Shahjahan Begum, 1876:232). The remarks made nearly 140 years ago still hold relevance with present day Bhopal's mosques including the Begumi Masjids constituting an integral part of the city's built heritage. As they are conserved for posterity, the mosques stand not only as important symbols of the Muslim faith but also as markers of their patrons' endeavor to position themselves at the forefront in the complex political and cultural scenario of post uprising colonial India.

\section{ACKNOWLEDGEMENT}

The Author gratefully acknowledges that part of the research for this Paper was conducted at the Library at the Indian Institute of Advanced Study, Shimla, Himachal Pradesh, India in OctoberNovember 2013. The images in this Paper have been reproduced from the following sources for which the Author remains grateful: Archaeological Survey of India (ASI), Photo Archives, New Delhi, India and Commissioner, Archaeology, Archives and Museums, Government of Madhya

Pradesh, Bhopal, Madhya Pradesh, India.

\section{REFERENCES}

ALI, SYED ASHFAQ. (1969) Bhopal-Past and Present. Bhopal: Jai Bharat Publishing House.

ANSARI, HUMAYUN K. (2002) The Woking mosque: A case study of Muslim engagement with British society since 1889, Immigrants \& Minorities, 21(3), 1-24, http://dx.doi.org/10.1080/02619288.2002.9975044

ARCHAMBAULT, HANNAH L. (2013) Becoming Mughal in the Nineteenth Century: The Case of the Bhopal Princely State, South Asia: Journal of South Asian Studies, 1-17, http://dx.doi.org/10.1080/00856401.2013.788465 
BARR, DAVID. W.K. (1908) Progress in the Native States of India during the past forty years, Journal of the Royal Society of Arts, 56(2887), 453-474, Stable URL: http://www.jstor. org/stable/41337964 <Accessed: 28/10/2013 02:18>

BHARGAVA, K.D. (1960) Descriptive List of Mutiny papers in the National Archives of India, Bhopal. New Delhi: National Archives of India, Volume I.

FORBES, ROSITA. (1939) India of the Princes. London: The Right Book Club.

GUPTA, NARAYANI. (1981) Delhi Between Two Empires: 1803-1931 - Society, Govt. \& Urban Growth. Delhi: Oxford University Press.

HEBER, REGINALD. (1829) Narrative of a Journey through the Upper Provinces of India, from Calcutta to Bombay, 1824-1825. London: John Murray, Vol. II, $4^{\text {th }}$ Edition.

KHAN, MOIN-UD DIN HASAN AND JIVANLAL, MUNSHI. (1898) Two Native Narratives of the Mutiny in Delhi. Charles T. Metcalfe (Tr.) London: Archibald Constable and Co.

KHAN, S.M. (2000) The Begums of Bhopal: a Dynasty of Women Rulers in Raj India. New York: I.B. Tauris. METCALF, BARBARA. (2011) Islam and Power in Colonial India: The Making and Unmaking of a Muslim Princess, The American Historical Review, 116(1), 1-30, Stable URL: http://www.jstor.org/stable/10.1086/ahr.116.1.1.

METCALF, T.R. (1989) An Imperial Vision: Indian Architecture and Britain's Raj. London: Faber and Faber.

QURESHI, S. (1969) Taj-ul-Masajid: An Unfinished Hymn in Sandstone. In ALI, SYED ASHFAQ. Bhopal-Past and Present. Bhopal: Jai Bharat Publishing House; Appendix 3, v-xii.

ROUSSELET, LOUIS. (1882) India and Its Native Princes: Travels in Central India. London: Bickers and Son.

SANDERSON, G. (1913) Types of Modern Indian Buildings at Delhi, Agra, Allahabad, Lucknow, Ajmer, Bhopal, Bikanir, Gwalior, Jaipur, Jodhpur and Udaipur. Allahabad: Government Press.

SANTELLI, S. et al. (2010) Indian Palaces and Mansions: The Forgotten Architectural Heritage of the Cities of Bhopal, Banaras, Gwalior, Srirangam and Karaikudi. Field Workshop of "Oriental Cities" Programme D.S.A. Architecture and Heritage.

SHAHJAHAN BEGUM, NAWAB. (1876) Taj-ul Ikbal Tarikh Bhopal (The Crown of Prosperity, the History of Bhopal). H. C. Barstow (Tr.) Calcutta: Thacker and Spink.

SHARMA, R.K. AND ALI, RAHMAN. (1980) Archaeology of Bhopal Region. Delhi: Agam Kala Prakashan.

SOBTI, M. (1994) 'Urban Form and Space in Islamic Cities: A Study of Morphology and Formal Structures in the city of Bhopal, Central India', Unpublished Under Graduate Thesis, CEPT, Ahmedabad, India.

SULTAN JAHAN BEGUM, NAWAB. (1912) Gohur-i-Ikbal (An Account of My Life). C.H. Payne (Tr.) London: John Murray.

VERMA, R. (1984) The Freedom Struggle in the Bhopal State. New Delhi: Intellectual Publishing House.
Sacralizing The City: The Begums of Bhopal and Their Mosques 


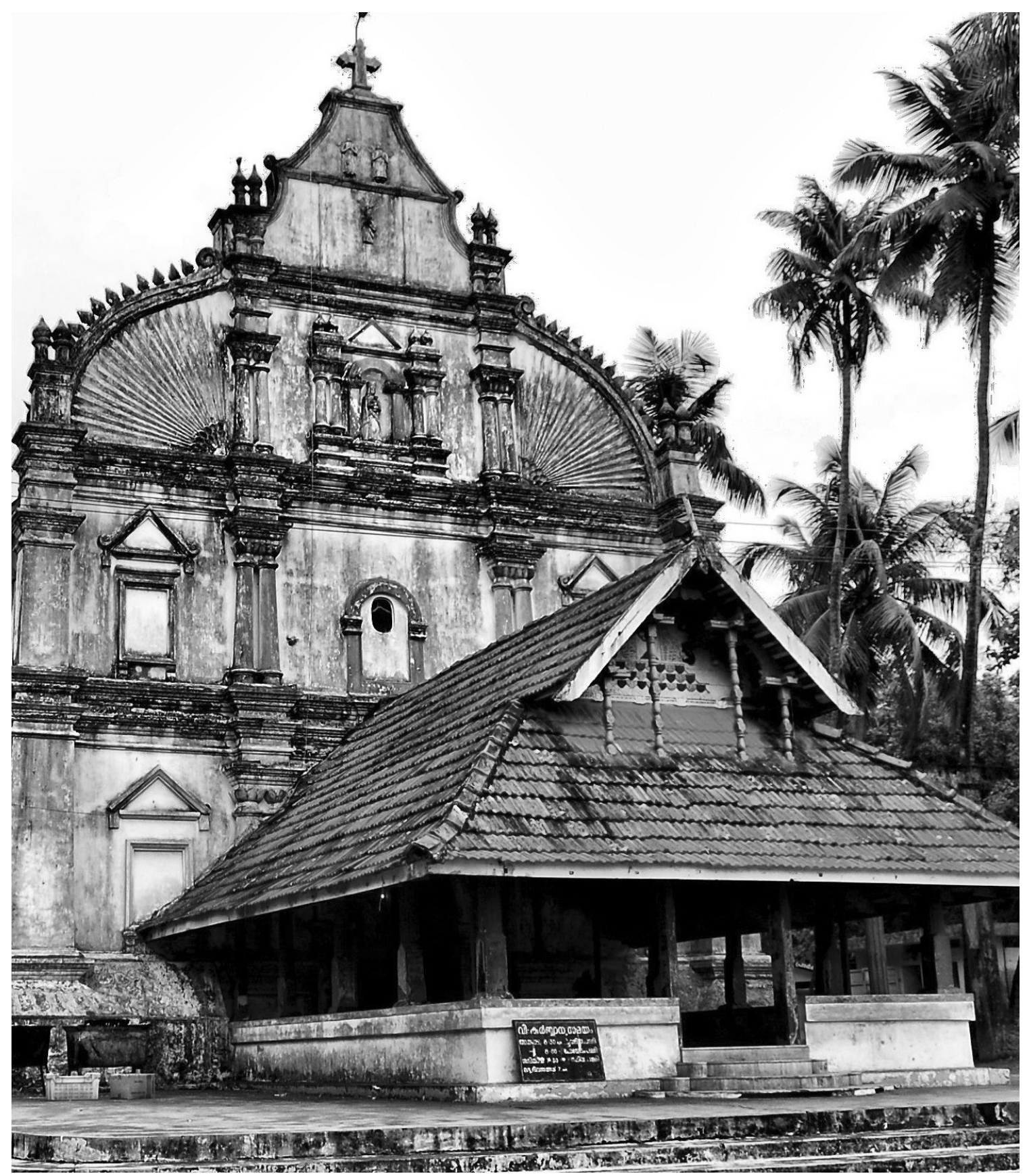

The Kadamattom church (Saint George Syrian Church), Kolenchery, Muvattupuzha, Kerala

(Image Source: http:://en.wikipedia.org/wiki/File:Kadamattom.jpg) [Accessed on 26.01.2014] 